\title{
Effects of Radio Frequency Heating and Storage Time on Physical and Chemical Properties of Rough Rice cv. Khao Dawk Mali 105
}

\author{
Wornwimol Wangspa ${ }^{1}$, Suchada Vearasilp ${ }^{1,3,4}$ *, and Yaowaluk Chanbang, ${ }^{1,2,4}$ \\ ${ }^{1}$ Postharvest Technology Research Center, Faculty of Agriculture, Chiang Mai University, \\ Chiang Mai 50200, Thailand \\ ${ }^{2}$ Department of Entomology and Plant Pathology, Faculty of Agriculture, Chiang Mai \\ University, Chiang Mai 50200, Thailand \\ ${ }^{3}$ Department of Plant and Soil Science, Faculty of Agriculture, Chiang Mai University, Chiang \\ Mai 50200, Thailand \\ ${ }^{4}$ Postharvest Technology Innovation Center, Commission on Higher Education, Bangkok \\ 10400, Thailand \\ *Corresponding author.E-mail: suchadachiangmai@gmail.com \\ https://doi.org/10.12982/CMUJNS.2018.0008
}

\begin{abstract}
As shown in prior research (Wangspa et al., 2015), radio frequency (RF) heat treatment at $65^{\circ} \mathrm{C}$ for 120 seconds is the appropriate combination to completely kill all stages of rice weevil (Sitophilus oryzae L.) in rough rice cv. Khao Dawk Mali 105. As a follow-on, this study evaluated the effects of this optimal RF combination on various properties of the rice relative to untreated control during storage for up to six months. Rough rice samples were treated with $\mathrm{RF} 65^{\circ} \mathrm{C}$ for 120 seconds, and packed in gunny-sacks and stored for up to six months at $25-32^{\circ} \mathrm{C}$, alongside the control. Every month, a portion of the untreated and $\mathbf{R F}$-treated rice was removed, milled and tested for physical (moisture content, color, and pasting) and chemical properties (amylose, protein, and 2-acetylpyrroline content) important to rice quality. Before storage, all properties of the untreated and $R F$-treated rice were similar, except for small, but significant changes, in amylose and 2-acetyl-1-pyrroline (2-AP). The storage-induced changes in the moisture content, head rice, amylose content, and protein content of the rice did not very between the untreated and $\boldsymbol{R} F$-treated rice over the entire period. Although there were small but significant differences in color (after many months of storage), pasting properties (during the middle months), and 2-AP (in some months) between the untreated and RF-treated rice during storage, the differences were all small enough to not significantly affect the quality or consumer acceptance of the rice compared to the untreated rice. Thus, RF-treatment (at $65^{\circ} \mathrm{C}$ for 120 seconds) can effectively control weevils in Thai Hom Mali rough rice, without adversely affecting important physical and chemical properties of the rice during storage compared to untreated rice.
\end{abstract}

Keywords: Rice quality, Pasting properties, Amylose content, Rice protein, 2-acetyl-1pyrroline 


\section{INTRODUCTION}

The price of Thai Hom Mali rice depends on various determinants of its quality. To maximize its value, it is imperative that growers and processors alike consider the best methods for postharvest handling of the grain. One major post-harvest threat to Thai Hom Mali rice is the inevitable emergence of rice weevils within the grain itself during storage. This is difficult, if not impossible, to control without the use of technological means. In the past, and to a lower extent today, rice weevils were controlled by fumigation. However, the chemicals affected the environment, posed dangers to those applying the fumigant, and increased resistance within the insects themselves, lessening its effectiveness.

Radio frequency (RF) heat treatment offers an alternative technology for controlling insects in stored products. Wangspa et al. (2015) reported that RF heat treatment at $65^{\circ} \mathrm{C}$ for 120 seconds was the optimal treatment for controlling rice weevil (Sitophilus oryzae Linnaeus) in rough rice cv. Khao Dawk Mali 105; it was the treatment that consumed the least energy $(0.391 \mathrm{kWh})$, while completely killing all stages of the weevil.

Another substantial threat posed to stored rice is the gradual degradation of its physical and chemical properties over time. Storage conditions, such as temperature, moisture content, and duration, affect the rate and type of degradation in grain quality. Storage physically alters the milling quality, grain color, pasting properties, and head rice percentage, among others. Rough rice stored at a high moisture content had low milling quality and a greater change in the color of the rice kernels (Trigo-Stockli and Pedersen, 1994; Yoshihashi et al., 2005). Storage also chemically alters the rice, including the levels of the distinctive aromatic compound 2-acetyl-1-pyrroline (2-AP), rice proteins like glutelin, and amylose. Harvested rice stored for prolonged periods will undergo distinct alterations in the mentioned chemical properties, hence serving as reliable markers of rice quality. For instance, it has been reported that when rough rice cv. Khao Dawk Mali 105 was stored at higher temperature, the 2-AP content quickly decreased (Yoshihashi et al., 2005). However, the fat acidity of the rice increased during storage, and was inversely correlated with the 2-AP content at early stages of storage (Champagne, 2008).

Some methods for minimizing these storage changes in rice include storing it as rough rice rather than milled rice, as the husk provides some protection (International Rice Research Institute, 2013). To prevent the inevitable increase in head rice during handling and storage, the rough rice is often parboiled (treated hydrothermally) before milling, as the milling yield of parboiled rice is higher and of better quality, due to fewer broken kernels, than non-parboiled rice (Itoh et al., 1985).

The effect of supplementing these storage treatments/methods with RF treatment has not been studied in Thai Hom Mali rice. Due to its ease of use and cost, RF treatment offers a potentially attractive method for reducing the degradation in stored rice. However, as it involves heat, the method may affect the physical and chemical properties of rice, and these alterations may further affect grain quality during subsequent storage. Therefore, this study investigated the effects of RF heat treatment at $65^{\circ} \mathrm{C}$ for 120 seconds (the previously determined optimum) on the physical and chemical properties of rough rice cv. Khao Dawk Mali 105 during storage of 0 to 6 months. 


\section{MATERIALS AND METHODS}

\section{Rice samples}

Control vs treatment. This experiment used rough rice cv. Khao Dawk Mali 105, grown in Chiang Dao District, Chiang Mai Province, Thailand. The moisture content of the rough rice was adjusted to about $14 \%$ before experimentation. The rough rice samples were divided into two groups - control (untreated) and experimental (RF-treatment). The experimental group was treated with RF at $27.12 \mathrm{MHz}$ at $65^{\circ} \mathrm{C}$ for 120 seconds.

Storage. Samples of both the untreated control and RF-treated rough rice samples were then stored for $0,1,2,3,4,5$, or 6 months (seven storage periods). All rice samples (2.5 $\mathrm{kg}$ each) were stored following standard grower practice; that is, by packing in gunnysacks and storing at an ambient temperature that ranged from $20^{\circ} \mathrm{C}$ to $30^{\circ} \mathrm{C}$. After each designated storage period, the samples were removed for further treatment and testing. The experiment was done in four replications.

Rough (un-milled) vs milled. Following each designated storage period, samples of both the untreated and RF-treated rough rice were removed. A portion of each was left in rough rice form and another portion was immediately milled. For the milled samples, the rough rice was de-husked and then polished using a TVC rice miller. The milled samples were further ground into rice flour using a cyclone sample mill for testing the pasting properties, amylose content, and protein content.

These experimental conditions - 1) untreated vs RF-treated rough rice, 2) storage of the rough rice for $0,1,2,3,4,5$, or 6 months, and 3) after storage, leaving as rough rice or milling - created 28 different samples; four each for each storage period (untreated rough, untreated milled, RF-treated rough, RF-treated milled). The rough rice samples were analyzed for moisture content; the milled rice samples were analyzed for a variety of physical and chemical properties.

\section{Moisture content (rough rice only)}

Moisture content, which is related to head rice yield, was determined using the ovendrying method; rough rice samples were ground in a sample mill (Foss Tecator, Cemotec, Denmark), then $5 \mathrm{~g} /$ replication were placed in aluminum moisture can and dried using a hotair oven at $130^{\circ} \mathrm{C}$ for 1 hour.

\section{Physical properties (milled rice)}

After each storage period, the untreated and RF-treated rough rice samples were milled separately and then analyzed for the following physical characteristics.

Percentage of head rice in milled rice. The milled rice samples were separated into broken and whole rice kernels to determine the percentage of head rice; by definition, whole rice included split kernels that retained at least $80 \%$ of the whole kernel area. To meet the minimum quality standard for Thai Hom Mali milled rice, the head rice must be at least 36\% (National Bureau of Agricultural Commodity and Food Standards, 2008).

Color of milled rice. Color of the milled rice was measured with a colorimeter (ColorQuest XE, Hunterlab, The Color Management Company, Reston, VA) using the CIE color scales $\mathrm{L}^{*}$ and $\mathrm{b}^{*} ; \mathrm{L}^{*}$ indicates the degree of brightness $(100)$ or darkness $(0)$ and ' $\mathrm{b}$ *' indicates the yellowness $(+b)$ or blueness $(-b)$ (Zhoung et al., 2014). 
Pasting properties of milled rice. The pasting properties of the milled rice samples were analyzed using a Rapid Visco Analyzer (RVA) (RVA-4D; Newport Scientific Warriwood, Australia). The pasting properties were determined by peak viscosity (the water-holding ability of rice starch), breakdown viscosity (difference in viscosity between the peak viscosity and holding strength), final viscosity (viscosity after cooling at $50^{\circ} \mathrm{C}$ for 1.40 minutes), setback viscosity (difference in viscosity between the final viscosity and the peak viscosity), and pasting temperature (increase in temperature for initial viscosity, in relation to the minimum temperature used to cook the rice). The values of the pasting properties were reported in centipoises $(\mathrm{cP})$.

\section{Chemical properties (milled rice)}

Quantity of 2-acetyl-1-pyrroline (2-AP) in milled rice. 2-acetyl-1-pyrroline, or 2-AP, is the major volatile component of Khao Dawk Mali 105 rice after treating with RF. The quantity of 2-AP was determined using a headspace-gas chromatograph (HS-GC) at the Center of Excellence for Innovation in Chemistry (PERCH-CIC), Department of Chemistry, Faculty of Science, Chiang Mai University, Chiang Mai.

Amylose content in milled rice. Amylose content, which is related to the water absorption of cooked rice grains, was determined by following the iodine-based colorimetry method of Mahmood et al. (2007). The amylose content of the ground samples was determined using a spectrophotometer. The results were compared to the standard for Khao Dawk Mali 105 milled rice of 12-17\% (National Bureau of Agricultural Commodity and Food Standards, 2008).

Protein content of milled rice. The protein content of the rice flour was determined using the dye-binding assay method of Bradford (1976). Briefly, $2 \mathrm{ml}$ of a dye solution (Coomassie Brilliant Blue) was added to $1 \mathrm{ml}$ of crude extract of rice protein and allowed to react for 5 minutes at room temperature $\left(25^{\circ} \mathrm{C}\right)$. The samples were measured for absorbance using a UV-VIS spectrophotometer at $595 \mathrm{~nm}$. The absorbance values were compared with those of standard protein (bovine serum albumin; BSA).

\section{RESULTS}

\section{Pre-storage}

Treating rough rice cv. Khao Dawk Mali 105 with $\mathrm{RF}$ waves at $27.12 \mathrm{MHz}, 65^{\circ} \mathrm{C}$, and 120 seconds did not alter the physical properties of the rice before storage compared to the untreated control $(P>0.05)$, including the moisture content before milling and, as measured after milling, the percentage of head rice, color (brightness, or $\mathrm{L}^{*}$, and yellowness, or $\mathrm{b}^{*}$ ) (Table 1), and pasting properties, including the peak, final, breakdown, and setback viscosities (Table 2).

In contrast, the RF treatment altered some of the chemical properties of the rice compared to the untreated control (both milled), as measured before storage. RF treatment significantly increased the amylose and 2-acetyl-1-pyrroline (2-AP) content of the RF-treated, milled rice compared to the untreated, milled control $(P<0.05)$, but did not affect the protein content, before storage (Table 3). 


\section{After storage}

Moisture content of rough rice. The moisture content of both the untreated and RFtreated rough rice samples decreased significantly during storage $(P<0.05)$, although the initial decline was followed by a small increase in the final months; this was related to the relative humidity of the environment (Figure 1). The storage temperature also affected the level of reduction in the moisture content of the stored rough rice samples (Figure 2).

These changes in moisture content were not significantly different $(P>0.05))$ between the untreated and RF-treated samples.

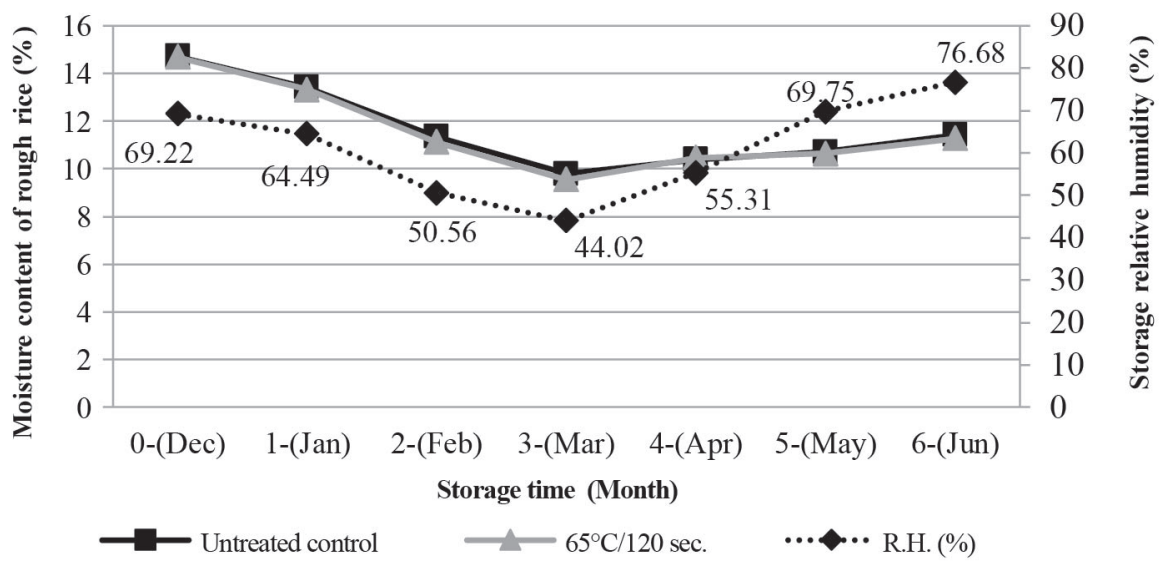

Figure 1. The ambient relative humidity values during rough rice storage compared with the moisture content of the untreated control and RF-treated rough rice.
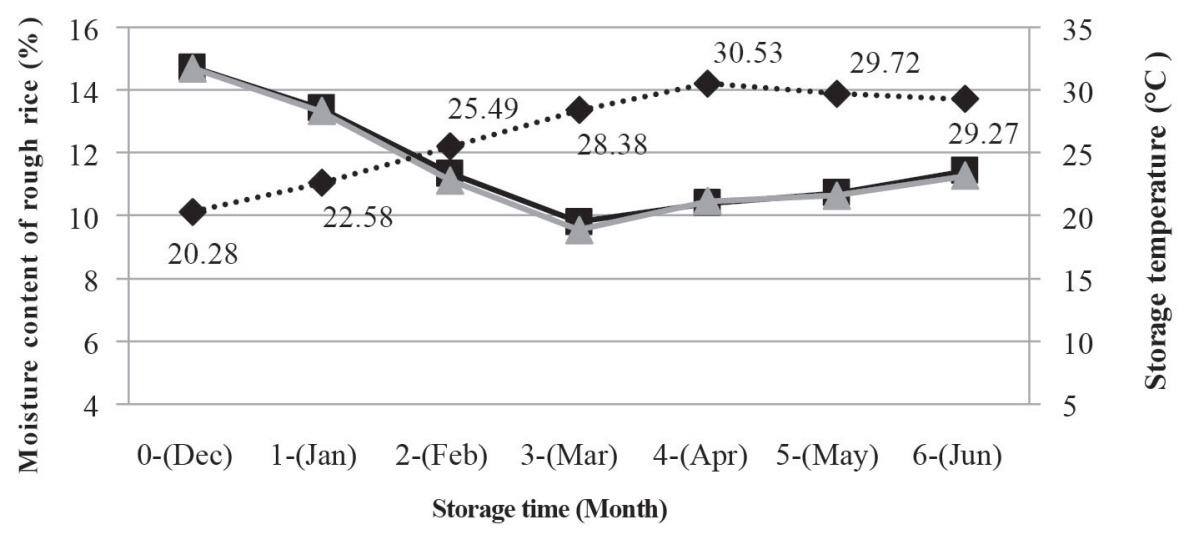

$\longrightarrow$ Untreated control

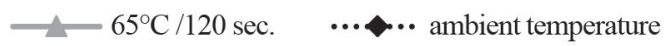

Figure 2. The ambient temperatures during rough rice storage compared with the moisture content of the untreated control and the RF-treated rough rice. 
Percentage of head rice of milled rice. After storing for six months and then milling, the percentage of head rice did not differ significantly $(P>0.05)$ between the untreated and RFtreated samples, and exceeded the minimum standard (Table 1). The percentage of head rice in both groups increased and reached maximal levels $(63.8 \pm 0.8 \%)$ after two months of storage (Table 1).

Color of milled rice. The color changes in the untreated and RF-treated rice (milled after storage) were not significantly different from each other through the first three months of storage. However, after storing as rough rice, the color of the subsequently milled, RF-treated rice became slightly more opaque $\left(\mathrm{L}^{*}\right)$ from month four onward, and yellow $\left(\mathrm{b}^{*}\right)$ from month five onward, than the milled, untreated rice.

Table 1. Comparing the effect of storage time on the moisture content (before milling), color ( $\mathrm{L}^{*}, \mathrm{~b}^{*}$; after milling), and percentage of head rice (after milling) of untreated and RF-treated rice.

\begin{tabular}{llcccc}
\hline \multirow{2}{*}{$\begin{array}{c}\text { Storage time } \\
\text { (month) }\end{array}$} & \multicolumn{1}{c}{ Treatment } & \multicolumn{3}{c}{ Physical properties $( \pm \mathbf{S E})^{\mathbf{1}}$} \\
\cline { 3 - 6 } No storage & Untreated control & $14.7 \pm 0.2 \mathrm{a}$ & $68.8 \pm 0.5 \mathrm{ab}$ & $13.6 \pm 0.1 \mathrm{j}$ & $49.2 \pm 0.3 \mathrm{def}$ \\
(December) & RF treatment & $14.7 \pm 0.1 \mathrm{a}$ & $69.9 \pm 0.1 \mathrm{ab}$ & $13.9 \pm 0.1 \mathrm{j}$ & $54.1 \pm 2.0 \mathrm{bcd}$ \\
\hline Month 1 & Untreated control & $13.4 \pm 0.2 \mathrm{~b}$ & $66.9 \pm 0.6 \mathrm{~cd}$ & $14.7 \pm 0.1 \mathrm{i}$ & $57.7 \pm 2.8 \mathrm{abc}$ \\
(January) & RF treatment & $13.3 \pm 0.4 \mathrm{~b}$ & $68.9 \pm 0.6 \mathrm{ab}$ & $15.8 \pm 0.3 \mathrm{gh}$ & $61.2 \pm 3.2 \mathrm{a}$ \\
\hline Month 2 & Untreated control & $11.4 \pm 0.4 \mathrm{c}$ & $68.8 \pm 0.2 \mathrm{ab}$ & $15.2 \pm 0.1 \mathrm{hi}$ & $61.7 \pm 2.7 \mathrm{a}$ \\
(February) & RF treatment & $11.1 \pm 0.2 \mathrm{~cd}$ & $69.0 \pm 0.3 \mathrm{ab}$ & $15.7 \pm 0.2 \mathrm{fg}$ & $63.8 \pm 0.8 \mathrm{a}$ \\
\hline Month 3 & Untreated control & $9.8 \pm 0.2 \mathrm{f}$ & $69.6 \pm 0.5 \mathrm{ab}$ & $16.0 \pm 0.1 \mathrm{efg}$ & $59.1 \pm 3.3 \mathrm{ab}$ \\
(March) & RF treatment & $9.5 \pm 0.2 \mathrm{f}$ & $69.7 \pm 0.4 \mathrm{ab}$ & $16.2 \pm 0.0 \mathrm{def}$ & $59.5 \pm 4.3 \mathrm{ab}$ \\
\hline Month 4 & Untreated control & $10.4 \pm 0.1 \mathrm{e}$ & $67.02 \pm 0.5 \mathrm{~cd}$ & $16.3 \pm 0.1 \mathrm{de}$ & $51.30 \pm 0.9 \mathrm{cde}$ \\
(April) & RF treatment & $10.5 \pm 0.1 \mathrm{e}$ & $69.7 \pm 0.3 \mathrm{ab}$ & $16.5 \pm 0.0 \mathrm{~cd}$ & $51.47 \pm 0.8 \mathrm{cde}$ \\
\hline Month 5 & Untreated control & $10.7 \pm 0.2 \mathrm{de}$ & $68.5 \pm 0.4 \mathrm{bc}$ & $16.6 \pm 0.2 \mathrm{~cd}$ & $49.4 \pm 1.7 \mathrm{def}$ \\
(May) & RF treatment & $10.6 \pm 0.0 \mathrm{de}$ & $70.0 \pm 0.4 \mathrm{a}$ & $17.5 \pm 0.3 \mathrm{ab}$ & $50.4 \pm 1.5 \mathrm{def}$ \\
\hline Month 6 & Untreated control & $11.4 \pm 0.1 \mathrm{c}$ & $66.7 \pm 1.3 \mathrm{c}$ & $17.0 \pm 0.2 \mathrm{bc}$ & $44.2 \pm 3.3 \mathrm{f}$ \\
(June) & RF treatment & $11.3 \pm 0.1 \mathrm{c}$ & $68.6 \pm 0.2 \mathrm{ab}$ & $17.7 \pm 0.1 \mathrm{a}$ & $46.1 \pm 1.3 \mathrm{ef}$ \\
\hline
\end{tabular}

Note: ${ }^{1}$ Means within the same column followed by different letters are significantly different at the 95\%-confidence level $(P<0.05)$ using Least Significant Difference (LSD).

Pasting properties of milled rice. After rough rice was stored for six months, the pasting properties of RF-treated milled rice did not differ significantly from those of the untreated control. However, from the first to fifth month of storage, the peak, final, and breakdown viscosities varied significantly $(P<0.05)$ between the untreated and RF-treated milled rice (Table 2). 
Table 2. Comparing the effect of storage time on the pasting properties of untreated and RF-treated rice (milled after storage and before testing).

\begin{tabular}{|c|c|c|c|c|c|c|}
\hline \multirow{3}{*}{$\begin{array}{l}\text { Storage time } \\
\text { (month) }\end{array}$} & \multirow{3}{*}{ Treatment } & \multicolumn{4}{|c|}{ Pasting properties } & \multirow{3}{*}{$\begin{array}{c}\text { Pasting tem- } \\
\text { perature } \\
\left({ }^{\circ} \mathrm{C}\right)\end{array}$} \\
\hline & & \multicolumn{4}{|c|}{ Viscosity (centipoises, $\mathrm{cP}$ ) $\pm \mathrm{SE}^{1}$} & \\
\hline & & Peak & Final & Breakdown & Setback & \\
\hline No storage & Untreated control & $2449 \pm 4.5 \mathrm{~h}$ & $2479 \pm 11.0 \mathrm{~g}$ & $904 \pm 3.2 \mathrm{gh}$ & $61.0 \pm 2.7 \mathrm{gh}$ & $93.8 \pm 0.5 \mathrm{~b}$ \\
\hline (December) & RF treatment & $2418 \pm 3.8 \mathrm{~h}$ & $2446 \pm 22.8 \mathrm{~g}$ & $844 \pm 16.0 \mathrm{~h}$ & $28.0 \pm 1.9 \mathrm{~h}$ & $95.0 \pm 0.6 \mathrm{a}$ \\
\hline Month 1 & Untreated control & $2974 \pm 7.5 \mathrm{~d}$ & $2843 \pm 24.0 \mathrm{e}$ & $1270.5 \pm 3.5 \mathrm{bc}$ & $162 \pm 17.5 \mathrm{f}$ & $91.7 \pm 0.1 \mathrm{bc}$ \\
\hline (January) & RF treatment & $3131 \pm 60.5 \mathrm{c}$ & $2760 \pm 48.3 \mathrm{f}$ & $1159.0 \pm 29.1 \mathrm{~d}$ & $82.0 \pm 15.7 \mathrm{~g}$ & $91.2 \pm 0.4 \mathrm{c}$ \\
\hline Month 2 & Untreated control & $2941 \pm 14.9 \mathrm{~d}$ & $3177 \pm 31.6 \mathrm{c}$ & $1295 \pm 37.5 \mathrm{bc}$ & $225 \pm 14.8 \mathrm{~d}$ & $92.3 \pm 0.4 \mathrm{bc}$ \\
\hline (February) & $\mathrm{RF}$ treatment & $2969 \pm 13.9 \mathrm{~d}$ & $3051 \pm 37.3 \mathrm{e}$ & $1188 \pm 18.3 \mathrm{~cd}$ & $182 \pm 5.3 \mathrm{ef}$ & $92.1 \pm 1.0 \mathrm{bc}$ \\
\hline Month 3 & Untreated control & $3365 \pm 15.8 \mathrm{a}$ & $3388 \pm 33.6 \mathrm{a}$ & $1335 \pm 5.9 \mathrm{a}$ & $222 \pm 32.2 \mathrm{de}$ & $91.7 \pm 0.7 \mathrm{bc}$ \\
\hline (March) & RF treatment & $3244 \pm 10.8 b$ & $3256 \pm 22.6 \mathrm{bc}$ & $1298 \pm 24.7 \mathrm{ab}$ & $169 \pm 5.2 \mathrm{f}$ & $92.1 \pm 0.6 \mathrm{bc}$ \\
\hline Month 4 & Untreated control & $2953 \pm 24.5 \mathrm{~d}$ & $3226 \pm 25.0 \mathrm{c}$ & $1123 \pm 42.0 \mathrm{~d}$ & $284 \pm 3.8 \mathrm{c}$ & $91.6 \pm 0.5 \mathrm{bc}$ \\
\hline (April) & RF treatment & $3066 \pm 20.3 \mathrm{c}$ & $3327 \pm 18.6 \mathrm{a}$ & $1143 \pm 38.2 \mathrm{~d}$ & $261 \pm 5.2 \mathrm{~cd}$ & $92.4 \pm 0.3 \mathrm{bc}$ \\
\hline Month 5 & Untreated control & $2657 \pm 11.4 \mathrm{~g}$ & $30878 \pm 23.4 \mathrm{e}$ & $993 \pm 16.0$ ef & $431 \pm 21.6 \mathrm{a}$ & $83.6 \pm 0.6 \mathrm{~d}$ \\
\hline (May) & RF treatment & $2843 \pm 38.6 \mathrm{e}$ & $3193 \pm 23.3 \mathrm{~cd}$ & $1049 \pm 42.5 \mathrm{e}$ & $351 \pm 25.0 \mathrm{~b}$ & $84.8 \pm 0.4 \mathrm{~d}$ \\
\hline Month 6 & Untreated control & $2754 \pm 21.5 \mathrm{f}$ & $3195 \pm 23.6 \mathrm{~cd}$ & $965 \pm 19.3 \mathrm{fg}$ & $441 \pm 5.3 \mathrm{a}$ & $84.8 \pm 0.5 \mathrm{~d}$ \\
\hline (June) & $\mathrm{RF}$ treatment & $2808 \pm 27.7$ ef & $3241 \pm 31.0 \mathrm{bc}$ & $1008 \pm 16.8$ ef & $433 \pm 4.9 \mathrm{a}$ & $84.4 \pm 0.4 \mathrm{~d}$ \\
\hline
\end{tabular}

Note: ${ }^{1}$ Means within the same column followed by different letters are significantly different at the 95\%-confidence level $(P<0.05)$ using Least Significant Difference (LSD).

Chemical properties. The changes in the amylose and protein content of RF-treated milled rice were not significantly different $(P>0.05)$ from those that occurred in the untreated milled rice during storage. In contrast, 2-AP decreased significantly $(P<0.05)$ in RF-treated rice compared to the untreated control during storage, despite the RF treatment initially increasing this parameter (Table 3). 
Table 3. Comparing the effect of storage time on the chemical properties of untreated and RF-treated rice (milled after storage and before testing).

\begin{tabular}{|c|c|c|c|c|}
\hline \multirow{2}{*}{$\begin{array}{l}\text { Storage time } \\
\text { (month) }\end{array}$} & \multirow[b]{2}{*}{ Treatment } & \multicolumn{3}{|c|}{ Chemical properties $\left( \pm \mathbf{S E}^{1}\right)$} \\
\hline & & $\begin{array}{c}\text { Amylose } \\
\text { content (\%) }\end{array}$ & $\begin{array}{c}\text { Protein content } \\
(\mathrm{mg} / \mathrm{g})\end{array}$ & $\begin{array}{l}2-\mathrm{AP} \\
(\mathrm{ppm})\end{array}$ \\
\hline No storage & Untreated control & $14.0 \pm 0.0 \mathrm{a}$ & $78.2 \pm 0.6 \mathrm{a}$ & $4.5 \pm 0.0 \mathrm{~b}$ \\
\hline (December) & RF treatment & $15.0 \pm 0.5 \mathrm{bcd}$ & $74.4 \pm 1.4 \mathrm{abc}$ & $4.9 \pm 0.2 \mathrm{a}$ \\
\hline Month 1 & Untreated control & $14.7 \pm 0.2 \mathrm{abc}$ & $76.6 \pm 0.3 \mathrm{a}$ & $4.1 \pm 0.1 \mathrm{c}$ \\
\hline (January) & $\mathrm{RF}$ treatment & $15.4 \pm 0.2 \mathrm{~cd}$ & $72.6 \pm 0.2 \mathrm{bcd}$ & $2.3 \pm 0.0 \mathrm{e}$ \\
\hline Month 2 & Untreated control & $16.9 \pm 0.1 \mathrm{fg}$ & $74.8 \pm 0.2 \mathrm{ab}$ & $2.8 \pm 0.0 \mathrm{~d}$ \\
\hline (February) & $\mathrm{RF}$ treatment & $18.8 \pm 0.1 \mathrm{~h}$ & $71.2 \pm 0.2$ bcde & $2.6 \pm 0.1 \mathrm{~d}$ \\
\hline Month 3 & Untreated control & $17.4 \pm 0.2 \mathrm{~g}$ & $71.8 \pm 0.1$ bcde & $1.3 \pm 0.0 \mathrm{gh}$ \\
\hline (March) & RF treatment & $17.7 \pm 0.1 \mathrm{~g}$ & $70.5 \pm 0.2 \mathrm{cdef}$ & $1.3 \pm 0.1 \mathrm{~h}$ \\
\hline Month 4 & Untreated control & $16.4 \pm 0.3 \mathrm{ef}$ & $68.0 \pm 0.4$ efgh & $1.6 \pm 0.0 \mathrm{f}$ \\
\hline (April) & RF treatment & $15.8 \pm 0.1 \mathrm{de}$ & $67.0 \pm 0.5 \mathrm{fgh}$ & $1.0 \pm 0.0 \mathrm{i}$ \\
\hline Month 5 & Untreated control & $17.0 \pm 0.4 \mathrm{fg}$ & $69.8 \pm 0.6 \mathrm{defg}$ & $1.6 \pm 0.0 \mathrm{fg}$ \\
\hline (May) & RF treatment & $17.2 \pm 0.4 \mathrm{fg}$ & $66.2 \pm 0.7 \mathrm{gh}$ & $1.7 \pm 0.3 \mathrm{f}$ \\
\hline Month 6 & Untreated control & $14.4 \pm 0.2 \mathrm{ab}$ & $65.0 \pm 1.2 \mathrm{hi}$ & $2.7 \pm 0.0 \mathrm{~d}$ \\
\hline (June) & $\mathrm{RF}$ treatment & $15.2 \pm 0.7 \mathrm{bcd}$ & $61.5 \pm 2.1 \mathrm{i}$ & $2.2 \pm 0.0 \mathrm{e}$ \\
\hline
\end{tabular}

Note: ${ }^{1}$ Means within the same column followed by different letters are significantly different at The 95\%-confidence level $(P<0.05)$ using Least Significant Difference (LSD).

\section{DISCUSSION}

Comparing the untreated to RF-treated rice before storage, all physical and chemical attributes were similar, except the RF-treatment caused small, but significant changes, in amylose and 2-acetyl-1-pyrroline (2-AP). Throughout storage, the changes in the physical properties of moisture content and head rice did not vary between the untreated and RF-treated rice, as well as in the chemical properties of amylose and protein content. While there were small but significant differences in color (after many months of storage), pasting properties (during the middle months), and 2-AP (in some months) between the untreated and RF-treated rice during storage, the differences were all small enough to not significantly affect the quality or consumer acceptance of the rice compared to the untreated rice. In addition, the changes that occurred to both the untreated and RF-treated rice over the various storage periods all remained within the limits of acceptable quality for Thai Hom Mali rice, and mostly reflected the changes that occur in rice with extended storage or exposure to high temperatures, rather than as a result of RF treatment.

The moisture content of the untreated and RF-treated rice responded similarly to the changes in the storage environment; RF-treatment did not change this parameter relative to the control. Of note, the moisture content of both the untreated and RF-treated rough rice decreased during the first three months of storage, then increased somewhat over the last three months, although not returning to pre-storage levels (Table 1). This reflected seasonal 
influences, as the rice was stored from December to June, bridging the winter, hot, and into the beginning of the rainy season in Thailand.

The percentage of head rice did not significantly differ $(P>0.05)$ between the untreated and RF-treated rice, both initially and throughout all storage durations. In addition, it exceeded the minimum standard (36\%) for Thai Hom Mali rice; RF-treatment did not adversely affect this parameter.

$\mathrm{RF}$ treatment at $65^{\circ} \mathrm{C}$ for 120 seconds caused only small changes in the color of the rice after many months of storage relative to the untreated rice (Table 1); while significant, the differences between the two were not noticeable to the naked eye. Other studies have reported that heating by $\mathrm{RF}$ at 60 to $70^{\circ} \mathrm{C}$ for about 3 minutes also increased $\mathrm{L}^{*}$ and $\mathrm{b}^{*}$ values relative to untreated rice, but like our study, did not substantially affect color differences as seen by the naked eye (Theanjumpol et al., 2007; Sumetha et al., 2009; Buapud et al., 2012, Srikam et al., 2014). As others have reported, heating with RF changes milled rice kernels from a translucent white color to a more opaque white, with a corresponding increase in brightness (L*) (Le et al., 2014; Srikam et al., 2014).

There were small but significant changes in the pasting properties during the middle months between the untreated and RF-treated rice, but these were not enough to affect their relative quality. Theanjumpol et al. (2007) also found small, but unimportant changes, in pasting properties after RF treatment at 45 to $60^{\circ} \mathrm{C}$ for 3 minutes. However, Sumrerath et al. $(2008 ; 2010)$ found significant changes in pasting properties after longer RF treatment $\left(60^{\circ} \mathrm{C}\right.$ for 5 to 15 minutes) relative to untreated rice. The significant decrease $(P<0.05)$ of setback and final viscosity in RF-treated milled rice compared to that of untreated milled rice during storage (Table 2) correlated with the report of Arns et al. (2015). This difference is a result of amylose leaching out from the rice starch granules during RF treatment (Sasaki et al., 2000; Arns et al., 2015).

Amylose is important to the texture characteristics of rice after cooking - the more, the harder the resultant cooked rice (Yu et al., 2009; Asghar et al., 2012). The significant increase $(P<0.05)$ in amylose in the RF-treated milled rice compared to the untreated milled rice before storage (Table 3) in our experiment correlated with Luechai et al. (2008), Sumetha et al. (2009), and Srikam et al. (2014); they all showed that RF heating of $27.12 \mathrm{MHz}$ at about 60 to $70^{\circ} \mathrm{C}$ for 120 to 180 seconds significantly increased the amylose in milled rice cv. Khao Dawk Mali 105. RF heat treatment might reduce the water molecules in rice starch granules and, thereby, strengthen the bonds between amylose molecules and precipitate the formation of lipid complexes and amylose (Chrastil, 1990; Denyer et al., 2001; Zavareze and Dias, 2011). Others have suggested that the increased amylose in RF-treated rice leads to harder cooked rice, adversely affecting its texture (Yu et al., 2009; Lu et al., 2013). However, by month four of storage, the amylose content did not differ between the RF-treated and untreated rice (Table 3). This result correlated with Patindol et al. (2005) and Abeysundara et al. (2017), who showed that high storage temperatures lowered amylose content in stored rice. The storage temperatures began to climb in the fourth month of our study, coincident with the arrival of the hot season.

RF-treatment did not affect the protein content of rice compared to untreated rice, both before and during storage. The protein content of both decreased continuously during storage, consistent with storage at high temperatures, as others have shown (Chrastil, 1990; Zhou et al., 2003; Li-hong et al., 2006). 
2-acetyl-1-pyrroline or 2-AP is an important aromatic compound in milled rice cv. Khao Dawk Mali 105. RF treatment significantly increased its level before storage compared to the untreated control (Table 3). Sansenya et al. (2017a; b) reported a similar result; gamma irradiation increased 2-AP in rice compared to non-irradiated rice due to the stress of irradiation damaging the tissue of rice kernels. Storage lowered 2-AP in the stored rice, both untreated and RF-treated. This is consistent with several studies that have shown that stored rice losses 2-AP when aromatic rice varieties were stored at high temperatures for extended periods of time (Maneenuam et al., 2014; Wongpornchai et al., 2004; Yoshihashi et al., 2005). By month six in our study, 2-AP was lower in the RF-treated rice compared to the untreated rice $(P<0.05)$, although the difference would have been too small to be noticed by consumers. In addition, the 2-AP that remained in the rice in this experiment after storage exceeded the minimum standard for milled rice cv. Khao Dawk Mali 105 (0.07 ppm) (Buttery et al., 1983).

\section{CONCLUSION}

The use of RF at $65^{\circ} \mathrm{C}$ for 120 seconds has been shown to effectively control rice weevils in rough rice cv. Khao Dawk Mali 105 (Wangspa et al., 2015). This study showed that this optimal RF treatment for weevils did not adversely affect the quality of the rice, both before and after storage up to six months, compared to untreated rice. The few measurable and significant differences that did occur between the untreated and RF-treated rice before storage - amylose and 2-acetyl-1-pyrroline (2-AP) - and during storage - color (after many months), pasting properties (during the middle months), and 2-AP (in some months) - were likely not large enough to be noticed by consumers. As such, RF-treatment (at $65^{\circ} \mathrm{C}$ for 120 seconds) can effectively control weevils in rough rice, without adversely affecting important physical and chemical properties of the rice during storage compared to untreated rice.

\section{ACKNOWLEDGEMENTS}

We thank the Postharvest Technology Research Center, Faculty of Agriculture, Chiang Mai University, the Postharvest Technology Innovation Center, Commission on Higher Education, Bangkok, Thailand, and the Graduate School, Chiang Mai University, for their research grants. We also thank Atthaboon Watthammawut at the Faculty of Medicine, Srinakharinwirot University and Monsicha Somrit at the Faculty of Science, Mahidol University for proofreading our manuscript. 


\section{REFERENCES}

Abeysundara, A., Navaratne, S., Wickramasinghe, I., and Ekanayake, D. 2017. Determination of changes of amylose and amylopectin content of paddy during early storage. International Journal of Science and Research (IJSR). 6(1): 2094-2097. https://doi. org/10.21275/ART20164500

Arns, B., Bartz, J., Radunz, M., do Evangelho, J.A., Pinto, V.Z., Zavareze, E.D.R., and Dias, A.R.G. 2015. Impact of heat-moisture treatment on rice starch, applied directly in grain paddy rice or in isolated starch. Food Science and Technology. 60(2): 708-713. http:// dx.doi.org/ 10.1016/j.lwt.2014.10.059

Asghar, S., Anjum, F.M., Amir, R.M., and Khan, M.A. 2012. Cooking and eating characteristics of Rice (Oryza sativa L.). Pakistan Journal of Food Sciences. 22(3): 128-132.

Bradford, M.M. 1976. A rapid and sensitive method for the quantitation of microgram quantities of protein utilizing the principle of protein dye binding. Analytical Biochemistry. 72(12): 248-254. https://doi.org/10.1016/0003-2697(76)90527-3

Buttery, R.G., Juliano, B.O., and Ling, L.C. 1983. Identification of rice aroma compound 2-acetyl-1-pyrroline in pandan leaves. Chemistry and Industry. 23: 478-479.

Buapud, A., Chanbang, Y., and Verasilp, S. 2012. Effects of radio frequency heating on Sitotroga cerealella (Olivier) and milling quality of rice cv. Khao Dawk Mali 105. Journal of Agriculture. 28(2): 137-144.

Champagne, E.T. 2008. Rice aroma and flavor: A literature review. Cereal Chemistry. 85(4): 445-454.

Chrastil, J. 1990. Protein-starch interactions in rice grains. Influence of storage on oryzenin and starch. Journal of Agricultural and Food Chemistry. 38(9): 1804-1809. https://doi. org/10.1021/jf00099a005

Denyer, K., Johnson, P., Zeeman, S., and Smith, A.M. 2001. The control of amylose synthesis. Journal of Plant Physiology. 158(4): 479-487. https://doi.org/10.1078/0176-161700360

International Rice Research Institute. 2013. Grain storage and pest management: Training manual grain storage. Postharvest Unit, Crop and Environmental Division, IRRI.

Itoh, K., Kawamura, S., and Ikeuchi, Y. 1985. Processing and milling of parboiled rice. Journal of Faculty of Agriculture Hokkaido University. 62(3): 312-324.

Le, T.Q., Songsermpong, S., Rumpagaporn, P., Suwanagul, A., and Wallapa, S. 2014. Microwave heating for accelerated aging of paddy and white rice. Australian Journal of Crop Science. 8(9): 1348-1358.

Li-hong, X., Bin-wu, C., Neng, D., and Zhi-wei, Z. 2006. Effects of proteins on RVA viscosity properties of rice. Chinese Journal of Rice Science. 20(5): 524-528.

Lu, S., Cik, T.-T., Lii, C.-y., Lai, P., and Chen, H.-H. 2013. Effect of amylose content on structure, texture and a-amylase reactivity of cooked rice. Food Science and Technology. 54(1): 224-228. http://dx.doi.org/10.1016/j.lwt.2013.05.028

Luechai, N., Sardsud, V., Chanbang, Y., and Krittigamas, N. 2008. Radio frequency treatment for controlling rice moth, Corcyra cephalonica (Stainton) and its effects on quality of milled rice cv. Khao Dawk Mali 105. Agricultural Science Journal. 39(3) (Suppl.): 347-350. 
Mahmood, T., Turner, M.A., and Stoddard, F.L. 2007. Comparison of methods for colorimetric amylose determination in cereal grains. Starch/Stärke. 59(8): 357-365. https://doi.org/ 10.1002/star.200700612

Maneenuam, T., Chanprasert, W., Rittiron, R., Prasertsak, A., and Wongpiyachon, S. 2014. Effect of storage temperatures and storage containers on 2-Acetyl-1-Pyrroline content in Hom Mali Rice. Agricultural Science Journal. 45(2) (Suppl.): 377-380.

National Bureau of Agricultural Commodity and Food Standards. 2008. Thai agricultural standard: Thai Hom Mali Rice. Bangkok, Thailand.

Patindol, J., Wang, Y.J., and Jane, J. 2005. Structure-Functionality changes in starch following rough rice storage. Starch/Stärke. 57(5): 197-207. https://doi.org/10.1002/ star.200400367

Sansenya, S., Hua, Y., Chumanee, S., and Winyakul, C. 2017a. Effect of gamma irradiation on the 2-acetyl-1-pyrroline content during growth of Thai black glutinous rice (Upland rice). Australian Journal of Crop Science. 11(5): 631-637. https://doi.org/10.21475/ ajcs.17.11.05.p286

Sansenya, S., Hua, Y., Chumanee, S., Phasai, K., and Sricheewin, C. 2017b. Effect of gamma irradiation on 2-Acetyl-1-pyrroline content, GABA content and volatile compounds of germinated rice (Thai upland rice). Plants. 6(2): 18. https://doi.org/10.3390/ plants6020018

Sasaki, T., Yasui, T., and Matsuki, J. 2000. Effect of amylose content on gelatinization, retrogradation, and pasting properties of starches from waxy and nonwaxy wheat and their F1 seeds. Cereal Chemistry. 77(1): 58-63. https://doi.org/10.1094/ CCHEM.2000.77.1.58

Srikam, C., Chanbang, Y., and Krittigamas, N. 2014. Use of radio frequency for controlling sawtoothed grain beetle (Oryzaephilus surinamensis) in milled rice cv. Khao Dawk Mali 105. Journal of Agriculture. 30(3): 253-262.

Sumetha, K., Chanbang, Y., Hengsawad, V., and Krittigamas, N. 2009. Effect of radio frequency on Rhyzopertha dominica (Fabricius) (Coleoptera: Bostrichidae) and quality of rice cv. Khao Dawk Mali 105. p. 97-104. In Proceeding of $6^{\text {th }}$ Conference of Agricultural Graduate Research. Chiang Mai University, 12-13 March 2009. Chiang Mai, Thailand.

Sumrerath, P., Thanapornpoonpong, S., and Vearasilp, S. 2008. Modifying cooking quality of Khao Dawk Mali 105 Rice by radio frequency. Agricultural Science Journal. 39(Suppl.): 354-358.

Sumrerath, P., Vearasilp, S., Krittigamas, N., Hörsten, D.V., Lücke, W., and Thanapornpoonpong, S. 2010. Postharvest quality improvement of rice cv. Pathum Thani 1 by radio frequency. Agricultural Science Journal. 41(Suppl.): 452-455.

Theanjumpol, P., Thanapornpoonpong, S., Pawelzik, E., and Vearasilp, S. 2007. Milled rice physical properties after various radio frequency heat treatment. In Conference on International Agricultural Research for Development. 9-11 October 2007. University of Kassel-Witzenhausen and University of Gottingen, Germany.

Trigo-Stockli, D.M., and Pedersen, J.R. 1994. Effect of rice storage conditions on the quality of milled rice. p. 706-711. In Proceedings of the 6th International Working Conference on Stored-product Protection. 17-23 April 1994. Canberra, Australia

Wangspa, W., Chanbang, Y., and Vearasilp, S. 2015. Radio frequency heat treatment for controlling rice weevil in rough rice cv. Khao Dawk Mali 105. Chiang Mai University Journal of Natural Science. 14(2): 189-197. https://doi.org/10.12982/cmujns.2015.0081 
Wongpornchai, S., Dumri, K., Jongkaewwattana, S., and Siri, B. 2004. Effect of drying methods and storage time on the Aroma and milling quality of rice (Oryza sativa L.) cv. Khao Dawk Mali 105. Food Chemistry. 87(3): 407-414. http://dx.doi.org/10.1016/ j.foodchem.2003.12.014

Yoshihashi, T., Thi Thu Huong, N., Surojanametakul, V., Tungtrakul, P., and Varanyanond, W. 2005. Effect of storage conditions on 2-acetyl-1-pyrroline content in aromatic rice variety, Khao Dawk Mali 105. Journal of Food Science. 70(1): S34-S37. https://doi. org/10.1111/j.1365-2621.2005.tb09061.x

Yu, S., Maa, Y., and Sun, D.-W. 2009. Impact of amylose content on starch retrogradation and texture of cooked milled rice during storage. Journal of Cereal Science. 50(2): 139-144. https://doi.org/10.1016/j.jcs.2009.04.003

Zavareze, E.R., and Dias, A.R.G. 2011. Impact of heart-moisture treatment and annealing in starches: A review. Carbohydrate Polymers. 83(2): 317-328. https://doi.org/10.1016/j. carbpol.2010.08.064

Zhoung, Y.J., Liu, W., Xu, X.F., Liu, C.M., and Tu, Z.C. 2014. Correlation Analysis between Color Parameters and Sensory Characteristics of Rice with Different Milling Degrees. Journal of Food Processing and Preservation. 38(4): 1890-1897. https://doi.org/10.1111/ jfpp. 12161

Zhou, Z., Robards, K., Helliwell, S., Blanchard, C., and Baxterb, G. 2003. Rice ageing. I. Effect of changes in protein on starch behavior. Starch/Stärke. 55(3-4): 162-169. https:// doi.org/10.1002/star.200390030 